\title{
Novel Microsatellite Markers Acquired from Rubus coreanus Miq. and Cross-Amplification in Other Rubus Species
}

\author{
Gi-An Lee ${ }^{1}$, Jae Young Song ${ }^{1}$, Heh-Ran Choi ${ }^{2}$, Jong-Wook Chung ${ }^{1}$, Young-Ah Jeon ${ }^{1}$, \\ Jung-Ro Lee ${ }^{1}$, Kyung-Ho Ma ${ }^{1}$ and Myung-Chul Lee ${ }^{1, *}$
}

1 National Agrobiodiversity Center, National Academy of Agricultural Science, Rural Development Administration, Jeonju 560-500, Korea; E-Mails: gkntl1@korea.kr (G.-A.L.); jysong77@korea.kr (J.Y.S.); jwchung73@korea.kr (J.-W.C.); yjeon@korea.kr (Y.-A.J.); jrmail@korea.kr (J.-R.L.); khma@korea.kr (K.-H.M.)

2 Black Raspberry R\&D Team, Gochanggun Agricultural Extension Center, Gochang, Jeollabuk-do 585-943, Korea; E-Mail: hehranchoi@korea.kr

* Author to whom correspondence should be addressed; E-Mail: mcleekor@korea.kr; Tel.: +82-63-238-4900; Fax: +82-63-238-4859.

Academic Editor: Derek J. McPhee

Received: 13 February 2015 / Accepted: 7 April 2015 / Published: 10 April 2015

\begin{abstract}
The Rubus genus consists of more than 600 species that are distributed globally. Only a few Rubus species, including raspberries and blueberries, have been domesticated. Genetic diversity within and between Rubus species is an important resource for breeding programs. We developed genomic microsatellite markers using an SSR-enriched $R$. coreanus library to study the diversity of the Rubus species. Microsatellite motifs were discovered in 546 of 646 unique clones, and a dinucleotide repeat was the most frequent (75.3\%) type of repeat. From 97 microsatellite loci with reproducible amplicons, we acquired 29 polymorphic microsatellite markers in the Rubus coreanus collection. The transferability values ranged from $59.8 \%$ to $84 \%$ across six Rubus species, and Rubus parvifolius had the highest transferability value (84\%). The average number of alleles and the polymorphism information content were 5.7 and 0.541 , respectively, in the $R$. coreanus collection. The diversity index of $R$. coreanus was similar to the values reported for other Rubus species. A phylogenetic dendrogram based on SSR profiles revealed that seven Rubus species could be allocated to three groups, and that $R$. coreanus was genetically close to Rubus crataegifolius (mountain berry). These new microsatellite markers might prove useful in studies of the genetic diversity, population structure, and evolutionary relationships among Rubus species.
\end{abstract}


Keywords: microsatellite; genetic diversity; transferability; Rubus genus

\section{Introduction}

The Rubus genus in the Rosaceae family consists of more than 600 species grouped in 12 subgenera. A few of these species, including raspberries, blackberries, dewberries, arctic fruits, and flowering raspberries, have been domesticated and are the focus of breeding programs [1]. Both cultivated and wild Rubus species have the potential to interact with other species belonging to different Rubus subgenera. Cross-fertilization within the Rubus genus implies that wild populations could be useful resources to improve domesticated species [2-4]. For this reason, Rubus coreanus, which is distributed throughout Southeast Asia, could be a valuable resource for breeding programs and the biotech industry $[5,6]$.

During the last few decades, molecular markers have been used to estimate the genetic diversity of Rubus populations. Studies focusing on the genetic diversity of Rubus species have been conducted using various types of molecular markers, including restriction fragment length polymorphisms, random amplified polymorphic DNA, simple sequence repeats (SSRs), and amplified fragment length polymorphisms (AFLP), in Rubus caucasicus L. [7], Rubus glaucus [8], Rubus idaeus [9,10], Rubus occidentalis [11,12], and other Rubus species [13-15]. Rubus idaeus and Rubus caesius hybrids have been surveyed using internal transcribed spacer markers [16]. Cross-amplification within these Rubus species involved AFLP and SSR markers [15].

More reliable molecular markers are needed to enhance genetic analyses of Rubus species. The objectives of this study were to develop novel genomic SSR markers using a microsatellite-enriched library of $R$. coreanus and to test their transferability across six other Rubus species. New microsatellite markers with polymorphisms and transferability across species might be valuable tools to evaluate genetic variability and identify genes controlling agronomic traits in the Rubus genus.

\section{Results and Discussion}

In this study, 684 positive colonies were randomly selected from an SSR-enriched library and sequenced. A total of $358 \mathrm{~kb}$ sequences were acquired in 684 clones, and 646 singleton sequences were used to search for SSR motifs. A total of $38(5.6 \%)$ of the 684 clones were duplicates. Microsatellite motifs were discovered in 546 clones. The enrichment efficiency of microsatellites $(84.5 \%)$ was higher than for groundnut at 68\% [17], Japanese apricot at 57.0\% [18], lychee at $52.0 \%$ [19], and Actinidia arguta at 74.2\% [20].

Most of the microsatellite motifs $(75.3 \%)$ were dinucleotide repeats, followed by trinucleotide repeats $(20.7 \%)$ and repeat motifs that were tetranucleotide or greater (4.0\%). Among the SSR motifs, $\mathrm{AG} / \mathrm{CT}$ and CTT/AAG represented the majority of di- and trinucleotide motifs at $57.1 \%$ and $6.0 \%$, respectively. This result corresponds to the general SSR motif distribution in dinucleotide motifs [21,22]. The most common repeat in plants is the AT repeat; however, it was rare (1.1\%) in this study. The AT motif is not suitable for hybridization, due to its autocomplementarity [23]. 
Among the 546 clones containing microsatellite motifs, 263 primer pairs were designed based on flanking SSR regions. The SSR motifs biased over the acquired sequences might affect primer variation. The divergent distribution of DNA fragments in the SSR-enriched library could introduce variation among crops [24]. In total, 97 (46.2\%) of the microsatellite markers covered by the 263 primer pairs were successfully amplified and had reproducible amplicons (Supplementary Table S1); the remaining markers had no amplicons or multi-bands between two $R$. coreanus accessions, and were thus excluded from further analysis.

We applied the 97 microsatellite markers to analyze their transferability to other Rubus species (Table 1). The results for six other Rubus species indicated that, except for eleven loci with no amplified products, $86(88.7 \%)$ of the microsatellite markers produced at least one amplicon in other Rubus species. A total of $26(26.8 \%)$ of the microsatellite markers had PCR products in all tested samples (Table 2 and Supplementary Table 1). The transferability values ranged from 59.8\% to $84 \%$ across six Rubus species. Rubus parvifolius had the highest transferability value (84\%), followed by Rubus ursinus (79.4\%) and R. idaeus (78.4\%); in contrast, Rubus crataegifolius had only $59.8 \%$ transferability.

Table 1. List of accessions belonging to the Rubus genus.

\begin{tabular}{cc}
\hline Rubus Species (Sample Size) & Accession no. \\
\hline & GCB0021 *, GCB0023, GCB0024, GCB0027, \\
GCB0029, GCB0030, GCB0032, GCB0033 *, \\
GCB0034, GCB0035, GCB0036, GCB0038, \\
GCB0040, GCB0041, GCB0042, GCB0043, \\
GCB0045, GCB0046, GCB0047, GCB0049, \\
GCB0051, GCB0052, GCB0054, GCB0055, \\
GCB0057, GCB0059, GCB0060, GCB0061, \\
R. crataegifolius var. subcuneatus (3) & GCB0062, GCB0063, GCB0118, GCB0119 \\
R. parvifolius (2) & GCB0001, GCB0002, GCB0120 \\
R. crataegifolius (4) & GCB0004, GCB0005 \\
R. fruticosus (3) & GCB0006, GCB0009, GCB0014, GCB0015 \\
R. idaeus (3) & GCB0066 \\
\hline
\end{tabular}

* Accessions used to check for amplicon production using the designed primer pairs.

Table 2. Transferability of 97 new microsatellite markers within the Rubus genus.

\begin{tabular}{|c|c|c|c|c|c|c|c|}
\hline & \multicolumn{7}{|c|}{ Rubus Species } \\
\hline & R. co * & R. p * & R. $i^{*}$ & R. $u$ * & $R \cdot f^{*}$ & R. $c s *$ & R. $c$ * \\
\hline $\begin{array}{c}\text { Mean } \\
\text { transferability }(\%)\end{array}$ & 100 & $\begin{array}{c}84 \\
(83.5-84.5)\end{array}$ & $\begin{array}{c}78.4 \\
(75.3-80.4)\end{array}$ & 79.4 & $\begin{array}{c}71.8 \\
(66.0-76.3)\end{array}$ & $\begin{array}{c}67.7 \\
(63.9-71.1)\end{array}$ & $\begin{array}{c}59.8 \\
(56.7-61.9)\end{array}$ \\
\hline
\end{tabular}

Among the transferable microsatellite markers, we identified 29 polymorphic markers in selected $R$. coreanus accessions, while the remaining markers were monomorphic. These 29 markers were used to create DNA profiles of 48 Rubus accessions ( $R$. coreanus, 32 accessions; other Rubus species, 
16 accessions). Polymorphism scores for 29 microsatellite markers were calculated for the $R$. coreanus collection and for other Rubus species (Table 3). The number of alleles $\left(\mathrm{N}_{\mathrm{A}}\right)$ varied among loci, and ranged from two to 13 (mean $=5.7$ alleles) alleles in $R$. coreanus and from four to 15 (mean $=9.6$ alleles) alleles in other Rubus species. Within the $R$. coreanus collection, the mean expected heterozygosity and observed heterozygosity were 0.582 and 0.558 , respectively, and the mean polymorphism information content (PIC) was 0.541 (range, 0.147-0.863). GB-RC-245 had the highest PIC value of $0.863\left(\mathrm{~N}_{\mathrm{A}}=13\right)$, followed by 0.826 for GB-RC-091 and GB-RC-247 $\left(\mathrm{N}_{\mathrm{A}}=8\right.$ and 10, respectively). Castillo et al. [25] reported 12 microsatellite markers from red raspberry (R. idaeus) and blackberry (Rubus L. hybrids), with an average PIC value of 0.55 in the red raspberry collection. Michael et al. [26] reported an average PIC value of 0.49 (mean $\mathrm{N}_{\mathrm{A}}=8.6$ ) using 21 polymorphic Rubus SSR primers in cultivated and wild black raspberry ( $R$. occidentalis L.) collections. Our results revealed a similar diversity index in the $R$. coreanus collection compared to previously reported microsatellite markers in other Rubus species. This implies that the microsatellite markers developed in this study might be useful for the genetic assessment of Rubus species with high transferability.

Microsatellite analyses of $R$. coreanus and the genetic relatedness among seven Rubus species based on SSR profiles were not previously reported, whereas several studies have focused on cultivated Rubus species such as red raspberry [10,25]. In this study, we constructed phylogenetic trees based on the DNA profiles of 48 Rubus accessions using 29 microsatellite loci. The Rubus species were divided into three groups (Figure 1). Rubus coreanus was genetically close to mountain berry ( $R$. crataegifolius) in the third group (G-3). The alleles of $R$. crataegifolius for the 29 microsatellite loci were similar to those of $R$. coreanus, although $R$. crataegifolius had low transferability (59.8\%). The first group (G-1) consisted of other mountain berries ( $R$. crataegifolius var. subcuneatus and $R$. parvifolius), while the second group (G-2) included blackberry (Rubus fruticosus and $R$. ursinus) and red raspberry. These microsatellite markers will be useful for studies of the genetic diversity, population structure, and evolutionary relationships among Rubus species.

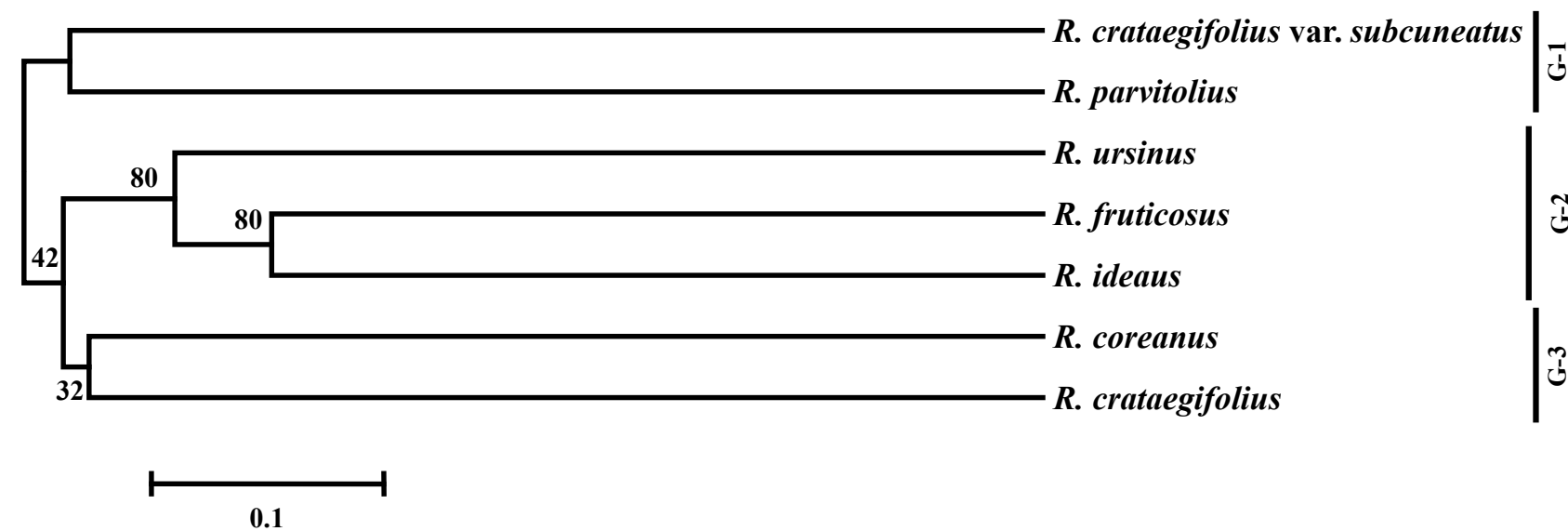

Figure 1. Phylogentic dendrogram based on SSR profiles in Rubus species. 
Table 3. Summary of the 29 polymorphic microsatellite markers in Rubus coreanus.

\begin{tabular}{|c|c|c|c|c|c|c|c|c|c|c|c|}
\hline \multirow{2}{*}{ Primer Name } & \multirow{2}{*}{ Genebank No } & \multirow{2}{*}{ Primer Sequence (5'-3') } & \multirow{2}{*}{ R-Motif } & \multirow{2}{*}{ Size Range } & \multicolumn{4}{|c|}{ R. coreanus } & \multicolumn{2}{|c|}{ Other Rubus sp. } & \multirow{2}{*}{$\operatorname{Tr} *$} \\
\hline & & & & & $\overline{\mathbf{N}_{A}}$ & Нo & $\mathrm{HE}_{\mathrm{E}}$ & PIC & $\mathbf{N}_{\mathbf{A}}$ & PIC & \\
\hline GB-RC-020 & JX976551 & $\begin{array}{l}\text { F-AAGCAATAATGGGTGGATCA } \\
\text { R-AATGGGAAGGCTGCAACT }\end{array}$ & $(\mathrm{GAA}) 9$ & $303-318$ & 4 & 0.607 & 0.696 & 0.647 & 8 & 0.809 & 50 \\
\hline GB-RC-049 & JX976552 & $\begin{array}{l}\text { F-ACAAGGTTGGTGAATGCG } \\
\text { R-ATTGCACTCTTCCGCTCA }\end{array}$ & $(\mathrm{GA}) 4$ & $196-210$ & 2 & 0.333 & 0.278 & 0.239 & 5 & 0.745 & 31.3 \\
\hline GB-RC-062 & JX976553 & $\begin{array}{l}\text { F-ACGACCCTTTGAATCGCT } \\
\text { R-GCGAGGCAAGTATTGGTG }\end{array}$ & $(\mathrm{ATG}) 5$ & $157-175$ & 3 & 0.25 & 0.279 & 0.255 & 4 & 0.639 & 37.5 \\
\hline GB-RC-067 & JX976554 & $\begin{array}{l}\text { F-AGAAGGTGTGCGAGACCC } \\
\text { R-AACCGTGTCACCGTGAAG }\end{array}$ & (AG)19 & $287-297$ & 6 & 0.233 & 0.584 & 0.557 & - & - & - \\
\hline GB-RC-074 & JX976555 & $\begin{array}{l}\text { F-AGAGTGGCCCTAGCCTTG } \\
\text { R-ACCCGATGAAGCTGGTTT }\end{array}$ & $(\mathrm{AG}) 15$ & $210-226$ & 6 & 0.613 & 0.482 & 0.446 & 10 & 0.815 & 93.8 \\
\hline GB-RC-077 & JX976557 & $\begin{array}{c}\text { F-AGCACCCTCTAAACCCGA } \\
\text { R-TGCTCATATATAATCGATGTGCTT }\end{array}$ & $(\mathrm{AAC}) 9$ & 194-208 & 6 & 0.742 & 0.552 & 0.508 & 7 & 0.565 & 93.8 \\
\hline GB-RC-078 & JX976558 & $\begin{array}{l}\text { F-AGCAGCATCATCAGTTCCA } \\
\text { R-TGCTTGGTGACCTCTGCT }\end{array}$ & $(\mathrm{GCA}) 6$ & $192-224$ & 5 & 0.774 & 0.699 & 0.643 & 14 & 0.904 & 81.3 \\
\hline GB-RC-091 & JX976559 & $\begin{array}{l}\text { F-ATCCCGAAAACCACCATT } \\
\text { R-CCTCTCTCTCCCCGTGAA }\end{array}$ & $(\mathrm{AG}) 15$ & $235-259$ & 8 & 0.281 & 0.845 & 0.826 & 11 & 0.844 & 81.3 \\
\hline GB-RC-098 & JX976560 & $\begin{array}{l}\text { F-ATGCCTCGATTGCAGAGA } \\
\text { R-GAACTCACAGCAGGTCGC }\end{array}$ & $(\mathrm{GCA}) 4$ & $201-216$ & 3 & 0.167 & 0.155 & 0.147 & 4 & 0.683 & 100 \\
\hline GB-RC-100 & JX976561 & $\begin{array}{l}\text { F-ATGTGCAGCAGCAGTGAA } \\
\text { R-CTGGGTCCATCCACATTG }\end{array}$ & $(\mathrm{AG}) 6$ & 210-286 & 8 & 0.548 & 0.771 & 0.741 & 11 & 0.852 & 100 \\
\hline GB-RC-105 & JX976562 & $\begin{array}{l}\text { F-ATTAAACCTCACCGGCGT } \\
\text { R-CAAGGCTTGTCAATTCGG }\end{array}$ & $(\mathrm{GT}) 8$ & $167-183$ & 4 & 0.969 & 0.626 & 0.566 & 9 & 0.798 & 93.8 \\
\hline GB-RC-109 & JX976563 & $\begin{array}{l}\text { F-CAAGAGTTGCATCGGCTC } \\
\text { R-TGTTGAAACTTTGCCATGC }\end{array}$ & (TC) 12 & 169-195 & 6 & 0.387 & 0.614 & 0.538 & 15 & 0.893 & 87.5 \\
\hline GB-RC-111 & JX976564 & $\begin{array}{l}\text { F-CAAGGCTTGTCAATTCGG } \\
\text { R-ATTAAACCTCACCGGCGT }\end{array}$ & $(\mathrm{CA}) 11$ & 170-184 & 4 & 0.968 & 0.623 & 0.56 & 8 & 0.753 & 93.8 \\
\hline GB-RC-138 & JX976565 & $\begin{array}{l}\text { F-CCACAAAACCAAGACCCA } \\
\text { R-AAGATAGATGAGGCCAGCG }\end{array}$ & $(\mathrm{ACACTC}) 4$ & 213-220 & 4 & 0.469 & 0.471 & 0.387 & 11 & 0.861 & 93.8 \\
\hline GB-RC-141 & JX976566 & $\begin{array}{l}\text { F-CCACAGAATGGGATTCATA } \\
\text { R-CTCGACTTGTCGCAGAGG }\end{array}$ & $(\mathrm{GA}) 6$ & 163-189 & 4 & 0.281 & 0.249 & 0.231 & 12 & 0.872 & 87.5 \\
\hline
\end{tabular}


Table 3. Cont

\begin{tabular}{|c|c|c|c|c|c|c|c|c|c|c|c|}
\hline \multirow{2}{*}{ Primer Name } & \multirow{2}{*}{ Genebank No } & \multirow{2}{*}{ Primer Sequence (5'-3') } & \multirow{2}{*}{ R-Motif } & \multirow{2}{*}{ Size Range } & \multicolumn{4}{|c|}{ R. coreanus } & \multicolumn{2}{|c|}{ Other Rubus sp. } & \multirow{2}{*}{$\operatorname{Tr} *$} \\
\hline & & & & & $\mathbf{N}_{\mathbf{A}}$ & Ho & $H_{E}$ & PIC & $\mathbf{N}_{\mathbf{A}}$ & PIC & \\
\hline GB-RC-143 & JX976567 & $\begin{array}{l}\text { F-CCACGGAGGACGTAATGA } \\
\text { R-CAGTCCAACTTGCTTCCG }\end{array}$ & (AG) 12 & $207-225$ & 6 & 0.719 & 0.625 & 0.564 & 10 & 0.81 & 62.5 \\
\hline GB-RC-145 & JX976568 & $\begin{array}{l}\text { F-CCATATGACACAGCCCAAA } \\
\text { R-CCATGCGACTTTACTGCC }\end{array}$ & $(\mathrm{AC}) 9,(\mathrm{CAA}) 5$ & $276-280$ & 3 & 0.188 & 0.246 & 0.222 & 6 & 0.672 & 100 \\
\hline GB-RC-166 & JX976570 & $\begin{array}{l}\text { F-CCTACGGCTTTGGTATGTT } \\
\text { R-CCCCCTTTCTCCTTCCTT }\end{array}$ & (TTGAAG)6 & $181-207$ & 5 & 0.625 & 0.751 & 0.71 & 12 & 0.871 & 93.8 \\
\hline GB-RC-167 & JX976571 & $\begin{array}{l}\text { F-CCTCATTTGCAAAGGTTCT } \\
\text { R-GACCGAACCATGATGGAA }\end{array}$ & (TC) 17 & $187-247$ & 12 & 0.759 & 0.819 & 0.796 & 14 & 0.884 & 81.3 \\
\hline GB-RC-178 & JX976572 & $\begin{array}{l}\text { F-CGCGCTAAACCACTTCAC } \\
\text { R-GTTGGAACAGCAGTGGGA }\end{array}$ & (CA) 15 & 167-191 & 6 & 1 & 0.67 & 0.618 & 11 & 0.829 & 81.3 \\
\hline GB-RC-186 & JX976573 & $\begin{array}{l}\text { F-CGTCCAATGTCTATCCGC } \\
\text { R-CAGGCAACTGCGATCTTC }\end{array}$ & (TTG)5 & 269-295 & 6 & 0.621 & 0.69 & 0.635 & 11 & 0.87 & 81.3 \\
\hline GB-RC-191 & JX976574 & $\begin{array}{l}\text { F-CTCAATGGGAGCACCAAA } \\
\text { R-CCCTGCCCAATAAGCATT }\end{array}$ & $(\mathrm{GA}) 6$ & $275-287$ & 7 & 0.862 & 0.797 & 0.772 & 12 & 0.803 & 93.8 \\
\hline GB-RC-193 & JX976575 & $\begin{array}{l}\text { F-CTCCCTGCAAAGAAAGCC } \\
\text { R-CTGGAATTCGCCCTTCTC }\end{array}$ & $(\mathrm{GA}) 18$ & $275-287$ & 7 & 0.857 & 0.782 & 0.753 & 9 & 0.804 & 81.3 \\
\hline GB-RC-207 & JX976577 & $\begin{array}{l}\text { F-CTTAGCCAGAACGGGGAG } \\
\text { R-CTAACCGGCTGGCCTACT }\end{array}$ & (GA) 10 & 219-231 & 6 & 0.643 & 0.577 & 0.512 & - & - & - \\
\hline GB-RC-211 & JX976578 & $\begin{array}{l}\text { F-CTTGGTGTGGATGCGATT } \\
\text { R-TTCCAGATTCGACCGTTG }\end{array}$ & $(\mathrm{GGA}) 7$ & $196-210$ & 6 & 0.5 & 0.556 & 0.527 & 8 & 0.838 & 100 \\
\hline GB-RC-220 & JX976579 & $\begin{array}{l}\text { F-GAATCAGGGTGAAGGGGA } \\
\text { R-CCСССТCTCTTCTTTTTGG }\end{array}$ & $(\mathrm{GA}) 14$ & $272-276$ & 2 & 0.379 & 0.307 & 0.26 & 9 & 0.797 & 62.5 \\
\hline GB-RC-245 & JX976582 & $\begin{array}{l}\text { F-GCCTCAAGCTCACACAGG } \\
\text { R-GGTGCGTCCACAAACTGT }\end{array}$ & $(\mathrm{AG}) 14$ & $262-350$ & 13 & 0.645 & 0.876 & 0.863 & 13 & 0.897 & 93.8 \\
\hline GB-RC-247 & JX976583 & $\begin{array}{l}\text { F-GCGCTATGGTCAGGTTGA } \\
\text { R-AAAGAAACGGTGGCCATT }\end{array}$ & (TTC) 12 & $278-338$ & 10 & 0.6 & 0.844 & 0.826 & 10 & 0.874 & 62.5 \\
\hline GB-RC-259 & JX976584 & $\begin{array}{c}\text { F-GGAAGGAATGCAATAGCCA } \\
\text { R-TCCCCCTGCTTCTGAGAT }\end{array}$ & $(\mathrm{TG}) 8$ & $315-317$ & 2 & 0.161 & 0.425 & 0.335 & 5 & 0.704 & 43.8 \\
\hline Mean & & & & & 5.7 & 0.558 & 0.582 & 0.541 & 9.6 & 0.803 & 80.1 \\
\hline
\end{tabular}

* Abbreviations: $\mathrm{N}_{\mathrm{A}}$, number of alleles; $\mathrm{H}_{\mathrm{O}}$, observed heterozygosity; $\mathrm{H}_{\mathrm{E}}$, expected heterozygosity; PIC, polymorphism information content. 


\section{Experimental Section}

\subsection{Plant Materials and Genomic DNA Extraction}

DNA was extracted from 48 Rubus accessions (32 R. coreanus accessions and 16 accessions of other Rubus species) that were conserved at the Bokbunja substation of the Gochang Agricultural Center (Table 1). Total genomic DNA was extracted from pulverized leaf samples using Plant DNAzol Reagent (Invitrogen, Carlsbad, CA, USA) according to the supplier's protocol. The DNA concentration was determined using an ultraviolet-visible spectrophotometer (ND-1000; NanoDrop, Wilmington, DE, USA). The final concentration of each DNA sample was adjusted to $20 \mathrm{ng} / \mu \mathrm{L}$ in TE buffer before implementing the PCR procedure.

\subsection{Construction of an SSR-Enriched Library and Primer Design}

A modified biotin-streptavidin capture method was used to construct an SSR-enriched library of R. coreanus [27]. Genomic DNA of $R$. coreanus was digested with restriction enzymes (AluI, DraI, HaeIII, RsaI, EcoRV, and $N r u \mathrm{I}$ ), and the fragmented DNA was eluted on a $1.5 \%$ agarose gel; the fragments ranged in size from 300 to $1500 \mathrm{bp}$. After adaptor ligation and pre-amplification, the DNA mixture was hybridized with the following biotin-labeled oligonucleotides: (GA) 20, (CA)20, (AT)20, (GC)20, (AGC)15, (GGC)15, (AAG)15, (AAC)15, and (AGG)15. The hybridized DNA fragments were recovered with streptavidin-coated magnetic beads (Promega, Madison, WI, USA). The fragments were cloned by TOPO TA cloning (Invitrogen). Recombinant colonies, identified as white colonies on an LB plate containing ampicillin, were sequenced using an ABI3100 DNA sequencer (Applied Biosystems, Foster City, CA, USA). SSR Manager [28] was used to identify the SSR motif and to design primers flanking these regions.

\subsection{PCR Amplification and Genotyping}

The M13-tailed primer method, in which the M13 sequence is attached to the 5'-end of the forward primer, was used to determine the sizes of the amplified products, as described by Schuelke [29]. PCR amplification was performed in a total volume of $20 \mu \mathrm{L}$, which consisted of $50 \mathrm{ng}$ of genomic DNA, 2 pmol of a specific primer, 4 pmol of the fluorescently labeled M13 universal primer (5'-TGT AAA ACG GCC AGT-3'), 6 pmol of a normal reverse primer, $2.0 \mu \mathrm{L}$ of $10 \times$ PCR buffer (Solgent, Daejeon, Korea), $1.6 \mu \mathrm{L}$ of a dNTP mixture $(2.5 \mathrm{mM})$, and $1 \mathrm{U}$ of Taq polymerase (Solgent). The reaction conditions were: $94{ }^{\circ} \mathrm{C}$ for $3 \mathrm{~min} ; 30$ cycles of $94{ }^{\circ} \mathrm{C}(30 \mathrm{~s}), 56{ }^{\circ} \mathrm{C}(45 \mathrm{~s})$, and $72{ }^{\circ} \mathrm{C}(1 \mathrm{~min})$; 10 cycles of $94{ }^{\circ} \mathrm{C}(30 \mathrm{~s}), 53{ }^{\circ} \mathrm{C}(45 \mathrm{~s})$, and $72{ }^{\circ} \mathrm{C}(1 \mathrm{~min})$; and a final extension step at $72{ }^{\circ} \mathrm{C}$ for 10 min. PCR was performed in a PTC-200 thermocycler (MJ Research, Waltham, MA, USA), and the amplified fluorescently labeled PCR products were resolved on an ABI PRISM 3130xl Genetic Analyzer (Applied Biosystems) with an internal size standard (Genescan-500 ROX). Fragments were sized and scored as alleles using GeneMapper ver. 4.0 (Applied Biosystems). 


\subsection{Analysis of Transferability, Genetic Variability, and Evolutionary Relationships}

The 97 microsatellite loci with a reproducible amplicon in $R$. coreanus were cross-amplified in other Rubus species, and their transferability was analyzed. PCR and resolving the amplified products were performed as described above. Genotypes of the 48 Rubus accessions were based on the 29 polymorphic microsatellite markers, and these DNA profiles were used to analyze genetic variability and construct a phylogenetic tree. PowerMarker (ver. 3.25) [30] was used to measure the genetic variability at SSR loci among Rubus species. A genetic distance matrix was created as a function of shared alleles [31]. The construction of a phylogenetic tree and bootstrapping were performed using PowerMarker (ver. 3.25) according to the un-weighted pair-group method with arithmetic averages. A consensus tree was created using the PHYLIP software package (ver. 3.695) [32].

\section{Conclusions}

We created 29 new polymorphic microsatellite markers based on the 97 transferable microsatellite markers in the Rubus species. The genetic diversity index and clustering results show that these markers are informative for genetic assessments of $R$. coreanus and other Rubus species. These new microsatellite markers can be used for genetic map construction, molecular breeding, and germplasm management of Rubus species.

\section{Supplementary Materials}

Supplementary materials can be accessed at: http://www.mdpi.com/1420-3049/20/04/6432/s1.

\section{Acknowledgments}

Research supported by the Research Program for Agricultural Science and Technology Development (Code no. PJ010883) from National Academy of Agricultural Science, Rural Development Administration, Republic of Korea.

\section{Author Contributions}

Gi-An Lee and Jae Young Song performed the experiments and wrote the paper and; Heh-Ran Choi contributed materials; Jong-Wook Chung, Young-Ah Jeon and Jung-Ro Lee analyzed the data; Kyung-Ho Ma and Myung-Chul Lee conceived and designed the experiments. All authors read and approved the final manuscript.

\section{Conflicts of Interest}

The authors declare no conflict of interest. 


\section{References}

1. Bushakra, J.; Stephens, M.; Atmadjaja, A.; Lewers, K.; Symonds, V.; Udall, J.; Chagné, D.; Buck, E.; Gardiner, S. Construction of black (Rubus occidentalis) and red (R. Idaeus) raspberry linkage maps and their comparison to the genomes of strawberry, apple, and peach. Theor. Appl. Genet. 2012, 125, 311-327.

2. Alice, L.A.; Campbell, C.S. Phylogeny of Rubus (Rosaceae) based on nuclear ribosomal DNA internal transcribed spacer region sequences. Am. J. Bot. 1999, 86, 81-97.

3. Alice, L.A.; Eriksson, T.; Eriksen, B.; Campbell, C.S. Hybridization and gene flow between distantly related species of Rubus (Rosaceae): Evidence from nuclear ribosomal DNA internal transcribed spacer region sequences. Syst. Bot. 2001, 26, 769-778.

4. Weber, H.E. Former and modern taxonomic treatment of the apomicticrubus complex. Folia Geobot. 1996, 31, 373-380.

5. Eu, G.-S.; Chung, B.-Y.; Bandopadhyay, R.; Yoo, N.-H.; Choi, D.; Yun, S. Phylogenic relationships of Rubus species revealed by randomly amplified polymorphic DNA markers. J. Crop Sci. Biotechnol. 2008, 11, 39-44.

6. Choi, H.; Kim, M.; Park, H.; Kim, Y.; Shin, D. Alcoholic fermentation of bokbunja (Rubus coreanus miq.) wine. Korean J. Food Sci. Technol. 2006, 38, 543-547.

7. Agar, G.; Halasz, J.; Ercisli, S. Genetic relationships among wild and cultivated blackberries (Rubus caucasicus L.) based on amplified fragment length polymorphism markers. Plant Biosyst. 2011, 145, 347-352.

8. Marulanda, M.; López, A.; Uribe, M. Molecular characterization of the andean blackberry, Rubus glaucus, using ssr markers. Genet. Mol. Res. 2012, 11, 322-331.

9. Parent, J.; Fortin, M.; Page, D. Identification of raspberry cultivars by random amplified polymorphic DNA (RAPD) analysis. Can. J. Plant Sci. 1993, 73, 1115-1122.

10. Graham, J.; Smith, K.; MacKenzie, K.; Jorgenson, L.; Hackett, C.; Powell, W. The construction of a genetic linkage map of red raspberry (Rubus idaeus subsp. idaeus) based on AFLPs, genomic-SSR and EST-SSR markers. Theor. Appl. Genet. 2004, 109, 740-749.

11. Parent, J.-G.; Pagé, D. Identification of raspberry cultivars by sequence characterized amplified region DNA analysis. HortScience 1998, 33, 140-142.

12. Dossett, M.; Bassil, N.; Finn, C. SSR fingerprinting of black raspberry cultivars shows discrepancies in identification. In Proceedings of the X International Rubus and Ribes Symposium 946, Zlatibor, Serbia, 22-26 June 2011; pp. 49-53.

13. Amsellem, L.; Noyer, J.; Le Bourgeois, T.; Hossaert-McKey, M. Comparison of genetic diversity of the invasive weed Rubus alceifolius Poir. (Rosaceae) in its native range and in areas of introduction, using amplified fragment length polymorphism (AFLP) markers. Mol. Ecol. 2000, 9 , 443-455.

14. Graham, J.; McNicol, R. An examination of the ability of RAPD markers to determine the relationships within and between rubus species. Theor. Appl. Genet. 1995, 90, 1128-1132. 
15. Lopes, M.; Maciel, G.; Mendonca, D.; Gil, F.S.; Da Câmara Machado, A. Isolation and characterization of simple sequence repeat loci in rubus hochstetterorum and their use in other species from the rosaceae family. Mol. Ecol. Notes 2006, 6, 750-752.

16. Alice, L.; Eriksson, T.; Eriksen, B.; Campbell, C. Intersubgeneric hybridization between a diploid raspberry, Rubus idaeus, and a tetraploid blackberry, R. caesius (Rosaceae). Am. J. Bot. 1997, 84, 171.

17. Cuc, L.M.; Mace, E.S.; Crouch, J.H.; Quang, V.D.; Long, T.D.; Varshney, R.K. Isolation and characterization of novel microsatellite markers and their application for diversity assessment in cultivated groundnut (Arachis hypogaea). BMC Plant Biol. 2008, 8, 55.

18. Kwon, S.-W.; Chung, J.-W.; Park, J.-W.; Lee, G.-A.; Ma, K.-H.; Lee, M.-C.; Park, Y.-J. Microsatellite variations and population structure in an on-farm collection of japanese apricot (Prunus mume Sieb. et Zucc.). Biochem. Syst. Ecol. 2012, 42, 99-112.

19. Viruel, M.; Hormaza, J. Development, characterization and variability analysis of microsatellites in lychee (Litchi chinensis Sonn., Sapindaceae). Theor. Appl. Genet. 2004, 108, 896-902.

20. Kwon, S.-J.; Lee, G.-A.; Kwack, Y.-B.; Lee, H.-S.; Cho, G.-T.; Ko, H.-C.; Lee, S.-Y.; Kim, Y.-G.; Ma, K.-H. Development of 34 new microsatellite markers from Actinidia arguta: Intra- and interspecies genetic analysis. Korean Soc. Breed. Sci. 2013, 1, 137-147.

21. Katti, M.V.; Ranjekar, P.K.; Gupta, V.S. Differential distribution of simple sequence repeats in eukaryotic genome sequences. Mol. Biol. Evol. 2001, 18, 1161-1167.

22. Cardle, L.; Ramsay, L.; Milbourne, D.; Macaulay, M.; Marshall, D.; Waugh, R. Computational and experimental characterization of physically clustered simple sequence repeats in plants. Genetics 2000, 156, 847-854.

23. Zhao, W.; Lee, G.-A.; Kwon, S.-W.; Ma, K.-H.; Lee, M.-C.; Park, Y.-J. Development and use of novel ssr markers for molecular genetic diversity in italian millet (Setaria italica L.). Genes Genomics 2012, 34, 51-57.

24. Gupta, P.K.; Varshney, R. The development and use of microsatellite markers for genetic analysis and plant breeding with emphasis on bread wheat. Euphytica 2000, 113, 163-185.

25. Castillo, N.R.; Reed, B.M.; Graham, J.; Fernández-Fernández, F.; Bassil, N.V. Microsatellite markers for raspberry and blackberry. J. Am. Soc. Hortic. Sci. 2010, 135, 271-278.

26. Dossett, M.; Bassil, N.V.; Lewers, K.S.; Finn, C.E. Genetic diversity in wild and cultivated black raspberry (Rubus occidentalis L.) evaluated by simple sequence repeat markers. Genet. Resour. Crop Evol. 2012, 59, 1849-1865.

27. Lee, G.-A.; Kwon, S.-J.; Park, Y.-J.; Lee, M.-C.; Kim, H.-H.; Lee, J.-S.; Lee, S.-Y.; Gwag, J.-G.; Kim, C.-K.; Ma, K.-H. Cross-amplification of ssr markers developed from Allium sativum to other Allium species. Sci. Hortic. 2011, 128, 401-407.

28. Kim, K. Developing one Step Program (SSR Manager) for Rapid Identification of Clones with SSRs and Primer Designing. Master's Thesis, Seoul National University, Seoul, South Korea, 2004.

29. Schuelke, M. An economic method for the fluorescent labeling of pcr fragments. Nat. Biotechnol. 2000, 18, 233-234.

30. Liu, K.; Muse, S.V. Powermarker: An integrated analysis environment for genetic marker analysis. Bioinformatics 2005, 21, 2128-2129. 
31. Chakraborty, R.; Jin, L. A unified approach to study hypervariable polymorphisms: Statistical considerations of determining relatedness and population distances. In DNA Fingerprinting: State of the Science; Birkhauser Verlag: Basel, Switzerland, 1993; pp. 153-175.

32. PHYLIP. Available online: http://evolution.genetics.washington.edu/phylip.html (accessed on 1 January 2015).

Sample Availability: DNA samples of the Rubus species germplasm are available from the authors.

(C) 2015 by the authors; licensee MDPI, Basel, Switzerland. This article is an open access article distributed under the terms and conditions of the Creative Commons Attribution license (http://creativecommons.org/licenses/by/4.0/). 